\title{
Antioxidative, Antifungal and Additive Activity of the Antimicrobial Peptides Leg1 and Leg2 from Chickpea
}

\author{
Marie-Louise Heymich ${ }^{1}$, Laura Niß1 ${ }^{2} \mathbb{D}$, Dominik Hahn ${ }^{1}$, Matthias Noll ${ }^{2} \mathbb{D}$ and Monika Pischetsrieder ${ }^{1, *(\mathbb{D})}$ \\ 1 Food Chemistry, Department of Chemistry and Pharmacy, Friedrich-Alexander Universität \\ Erlangen-Nürnberg (FAU), Nikolaus-Fiebiger-Str. 10, 91058 Erlangen, Germany; \\ marie-louise.heymich@fau.de (M.-L.H.); dominik.hahn@fau.de (D.H.) \\ 2 Institute for Bioanalysis, Department of Applied Sciences, Coburg University of Applied Sciences and Arts, \\ Friedrich-Streib-Str. 2, 96450 Coburg, Germany; lauraniss1@web.de (L.N.); matthias.noll@hs-coburg.de (M.N.) \\ * Correspondence: monika.pischetsrieder@fau.de
}

check for

updates

Citation: Heymich, M.-L.; Nißl, L.; Hahn, D.; Noll, M.; Pischetsrieder, M. Antioxidative, Antifungal and Additive Activity of the Antimicrobial Peptides Leg1 and Leg2 from Chickpea. Foods 2021, 10, 585. https://doi.org/10.3390/ foods10030585

Academic Editors: María Consuelo Pina-Pérez and Maria Vargas

Received: 3 February 2021

Accepted: 4 March 2021

Published: 11 March 2021

Publisher's Note: MDPI stays neutral with regard to jurisdictional claims in published maps and institutional affiliations.

Copyright: (c) 2021 by the authors. Licensee MDPI, Basel, Switzerland. This article is an open access article distributed under the terms and conditions of the Creative Commons Attribution (CC BY) license (https:// creativecommons.org/licenses/by/ $4.0 /)$.

\begin{abstract}
The fight against food waste benefits from novel agents inhibiting spoilage. The present study investigated the preservative potential of the antimicrobial peptides Leg1 (RIKTVTSFDLPALRFLKL) and Leg2 (RIKTVTSFDLPALRWLKL) recently identified in chickpea legumin hydrolysates. Checkerboard assays revealed strong additive antimicrobial effects of Leg1/Leg2 with sodium benzoate against Escherichia coli and Bacillus subtilis with fractional inhibitory concentrations of 0.625 and 0.75. Additionally, Leg1/Leg2 displayed antifungal activity with minimum inhibitory concentrations of 500/250 $\mu \mathrm{M}$ against Saccharomyces cerevisiae and 250/125 $\mu \mathrm{M}$ against Zygosaccharomyces bailii. In contrast, no cytotoxic effects were observed against human Caco-2 cells at concentrations below $2000 \mu \mathrm{M}$ (Leg1) and $1000 \mu \mathrm{M}$ (Leg2). Particularly Leg2 showed antioxidative activity by radical scavenging and reducing mechanisms (maximally $91.5 / 86.3 \%$ compared to $91.2 / 94.7 \%$ for the control ascorbic acid). The present results demonstrate that Leg1/Leg2 have the potential to be applied as preservatives protecting food and other products against bacterial, fungal and oxidative spoilage.
\end{abstract}

Keywords: antifungal activity; antimicrobial peptides; antioxidative peptides; chickpea peptides; cytotoxicity; Leg1; Leg2

\section{Introduction}

Peptides occur naturally in many foods or can be formed after the enzymatic or microbiological hydrolysis of food proteins. Dietary peptide fractions feature a huge structural variety and diverse bioactive properties including, among others, antioxidative, antihypertensive, antimicrobial, anti-inflammatory, anticancer and antithrombotic activities [1]. Particularly antimicrobial peptides (AMPs) from food sources could be a promising alternative to conventional preservatives. It has been postulated that AMPs interact specifically with the bacterial cell membrane and lead to its disintegration, for example by the formation of pores [2]. Thus, AMPs are active against a wide range of bacteria and are less likely to evoke antimicrobial resistance $[2,3]$. The risk of toxic side effects is low so that food-derived AMPs are generally considered as safe. Similarly, enzymatically generated AMPs from food proteins are equivalent to products of gastrointestinal digestion and most probably safe. So far, however, only one peptide is utilized as food preservative, namely nisin, which is of bacterial origin [4].

Recently, the antimicrobial peptides Leg1 (RIKTVTSFDLPALRFLKL) and Leg2 (RIKTVTSFDLPALRWLKL) (Figure 1) were identified in enzymatic hydrolysates of chickpea storage protein [5]. Both peptides were active against 16 strains of food spoilage bacteria and food pathogens. With minimum inhibitory concentrations (MIC) down to $15.6 \mu \mathrm{M}$, the peptides proved 10-1000-fold more active than conventional preservatives under the applied conditions. 
A

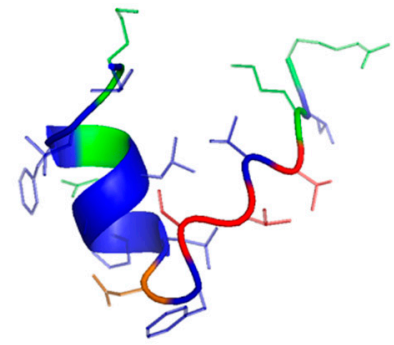

RIKTVTSFDLPALRFLKL
B

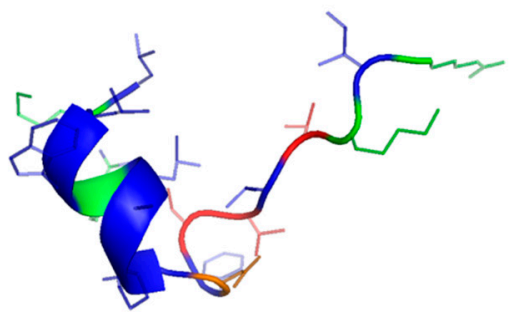

RIKTVTSFDLPALRWLKL

Figure 1. Peptide sequence and secondary structure of (A) Leg1 and (B) Leg2 [5] predicted with I-Tasser (https: / / zhanglab.ccmb.med.umich.edu/I-TASSER/, accessed on 22 May 2019) and generated by PyMOL (http:/ /www.pymol.org/, accessed on 13 January 2021). Hydrophobic amino acids are colored in blue, polar amino acids in red, positively charged amino acids in green and negatively charged amino acids in orange.

Besides preventing bacterial spoilage, however, bioactive peptides could improve the food's shelf life by antioxidative activity or cooperative effects with other preservatives. Additionally, peptides with antifungal activity [6] would be an asset against waste. Fungal spoilage of foods and beverages with high sugar contents, low $\mathrm{pH}$ and low water activities leads to major economic problems [7]. Globally, only a few yeast species are responsible for major losses in processed foods [8]. Among others, yeasts of the genera Zygosaccharomyces and Saccharomyces spoil food and drinks on a large scale. Especially Zygosaccharomyces (Z.) bailii pose a problem, because they show extreme osmotolerance, the ability to ferment hexose sugars and resistance to weak-acid preservatives [9-11].

Mold and yeast species differ in cell wall and membrane organization among each other and from bacteria, so that antimicrobial and antifungal activities of peptides do not necessarily coincide. The aim of the present study was to investigate if the newly detected food-derived AMPs Leg1 and Leg2 from chickpea [5] have an impact on other food spoilage processes including oxidation and fungal growth. Considering the different mechanisms of action of AMPs compared to low-molecular preservatives, we examined also if Leg1 and Leg2 may potentiate the activity of the conventional preservative sodium benzoate. Cooperative effects between combined preservatives may reduce the single concentrations required for effective food preservation.

\section{Materials and Methods}

\subsection{Peptide Synthesis}

Leg1 (RIKTVTSFDLPALRFLKL, molecular weight (MW) $2118.59 \mathrm{~g} / \mathrm{mol}$ ) and Leg2 (RIKTVTSFDLPALRWLKL, MW $2157.62 \mathrm{~g} / \mathrm{mol}$ ) were commercially produced by solidphase synthesis at ChinaPeptides Co. (Shanghai, China) and provided as trifluoroacetic acid salt-lyophilized powder (purity $>95 \%$ ). The quality of the products was verified as described before by ultrahigh-performance liquid chromatography (UHPLC; Ultimate 3000 RS, Thermo Fisher Scientific, Idstein, Germany) coupled to a TripleQuad $6500^{+}$mass spectrometer (AB Sciex, Darmstadt, Germany), equipped with duospray ion source [5]. The correct purity and mass were confirmed by enhanced mass spectrum full-scan analysis and the correct peptide sequence by enhanced product ion scan. The peptides were solved in sterile water $(2 \mathrm{mM})$ and stored at $-20^{\circ} \mathrm{C}$ until use.

\subsection{Bacterial and Fungal Strains and Culture Conditions}

Escherichia (E.) coli NEB $5 \alpha$ were obtained from New England Biolabs (Ipswich, MA, USA) and Bacillus (B). subtilis ATCC 6051 from the Leibniz Institute DSZM-German Collection of Microorganisms and Cell Cultures (Braunschweig, Germany). The bacteria were grown in nutrient broth $(8 \mathrm{~g} / \mathrm{L})$ at $37^{\circ} \mathrm{C}$ for $24 \mathrm{~h}$ under shaking in a temperature-controlled incubator shaker (Innova42R, New Brunswick, New York, NY, USA) as described by Heymich et al. [5]. DSZM also supplied the mold strain Aspergillus (A.) niger DSM 12634 
and the yeasts Pichia (P.) membranifaciens DSM 70633, Saccharomyces (S.) cerevisiae DSM 70499 and Z. bailii DSM 70492. A. niger was transferred to potato dextrose bouillon (PDB) agar plates (26.5 g/L PDB). The other fungal strains were cultured on universal medium for yeasts agar plates $(1.5 \%(w / v)$ yeast/molds (YM) agar; $3 \mathrm{~g} / \mathrm{L}$ yeast extract, $3 \mathrm{~g} / \mathrm{L}$ malt extract, $5 \mathrm{~g} / \mathrm{L}$ peptone from soybeans, $10 \mathrm{~g} / \mathrm{L}$ glucose). All media components were obtained from Carl Roth (Karlsruhe, Germany).

The concentration of the bacterial suspension was calculated by optical density at $600 \mathrm{~nm}\left(\mathrm{OD}_{600}\right)$ using a UV-visible spectrophotometer (Genesys 10S, Thermo Fisher Scientific) with nutrient broth as reference. The colony-forming unit rates per milliliter $(\mathrm{cfu} / \mathrm{mL})$ were calculated for E. coli $\left(1.0 \mathrm{OD}=8 \times 10^{8} \mathrm{cfu} / \mathrm{mL}\right)$ and B. subtilis $\left(1.0 \mathrm{OD}=8 \times 10^{9} \mathrm{cfu} / \mathrm{mL}\right)$ and the suspensions were diluted with nutrient broth to the appropriate concentration for each assay. Yeast inoculum suspensions were prepared in YM medium as described by Arendrup et al. [12] and were adjusted to a count of $9.0 \times 10^{4}$ to $1.0 \times 10^{5} \mathrm{cfu} / \mathrm{mL}$ (corresponding to $\mathrm{OD}_{620}$ of 0.12 to 0.15 measured by a UV-visible spectrophotometer, Analytik Jena, Jena, Germany). The mold inoculum was prepared in PDB and adjusted to a cell number of $1.0 \times 10^{6}$ spores $/ \mathrm{mL}$ by a Neubauer chamber (depth $0.1 \mathrm{~mm}$; Paul Marienfeld, LaudaKönigshofen, Germany) as described by Arendrup et al. [13].

\subsection{Checkerboard Assay to Test for Combinatorial Effects of Leg1/Leg2 and Sodium Benzoate}

To test for synergistic or additive effects, a checkerboard assay with resazurin was performed according to Sarker et al. [14] with small modifications. A resazurin solution was prepared solving one tablet (Thermo Fisher Scientific) in $50 \mathrm{~mL}$ of water, followed by sterile filtration (pore size $0.22 \mu \mathrm{m})$. The peptides Leg1, Leg2 or nisin (2.5\%, Sigma-Aldrich, Steinheim Germany) (0-500 $\mu \mathrm{M}$ each) and sodium benzoate (0-160,000 $\mu \mathrm{M}$, Sigma-Aldrich) were tested against E. coli and B. subtilis separately or in combination. Twenty-five $\mu \mathrm{M}$ ampicillin (ampicillin sodium salt, Carl Roth) was used as positive and sterilized water as negative control. Either a combination of $25 \mu \mathrm{L}$ of peptide solution and $25 \mu \mathrm{L}$ of sodium benzoate or $50 \mu \mathrm{L}$ of each single substance was transferred to 96-well microtiter plates (Greiner BioOne, Kremsmünster, Austria) in a two-fold dilution. Then $30 \mu \mathrm{L}$ of nutrient broth, $10 \mu \mathrm{L}$ of resazurin solution $(6 \mathrm{mg} / \mathrm{mL})$ and $10 \mu \mathrm{L}$ of the bacterial suspension $\left(1-5 \times 10^{6} \mathrm{cfu} / \mathrm{mL}\right)$ were added. After an incubation time of $16 \mathrm{~h}$ at $37^{\circ} \mathrm{C}$, the plates were measured at $\mathrm{OD}_{570}$ using a microplate reader ( $\mu$ Quant, Biotek, Bad Friedrichshall, Germany). MIC was defined as the lowest concentration at which no bacterial growth as indicated by a color change from blue to pink was observed. The fractional inhibitory concentration (FIC) index was calculated by the sum of the divided MIC values as follows:

$$
\mathrm{FIC}=\mathrm{FIC}_{\mathrm{A}}+\mathrm{FIC}_{\mathrm{B}}=\frac{\mathrm{MIC}_{\mathrm{AB}}}{\mathrm{MIC}_{\mathrm{A}}}+\frac{\mathrm{MIC}_{\mathrm{BA}}}{\mathrm{MIC}_{\mathrm{B}}} .
$$

where $\mathrm{MIC}_{\mathrm{A}}$ is the MIC of the single peptides Leg1, Leg2, or nisin, respectively, $\mathrm{MIC}_{\mathrm{B}}$ is the $\mathrm{MIC}$ of sodium benzoate alone, and $\mathrm{MIC}_{\mathrm{AB}}$ and $\mathrm{MIC}_{\mathrm{BA}}$ are the $\mathrm{MIC}$ concentrations of the substances in combination. FIC values $<0.5$ were interpreted as synergy, $0.5<\mathrm{FIC}>2.0$ as additivity, $2.0<$ FIC $>4.0$ as indifference and FIC $>4.0$ as antagonism. All experiments were performed in triplicates and repeated twice.

\subsection{Antifungal Susceptibility Tests}

The antifungal assays were performed as described previously by Arendrup et al. [12,13] with minor modifications. The peptides Leg1, Leg2, and nisin were tested in a concentration range of $1-1000 \mu \mathrm{M}$ and sodium benzoate at 156-160,000 $\mu \mathrm{M}$. The MIC values of $A$. niger, P. membranifaciens, Z. bailii, and S. cerevisiae were determined in vitro in triplicates in a 96well microtiter plate setup by a broth microdilution method. Each well contained $50 \mu \mathrm{L}$ of peptides/sodium benzoate, $25 \mu \mathrm{L}$ of fourfold concentrated medium (YM bouillon or PDB) and $25 \mu \mathrm{L}$ of yeast or mold inoculum. The microtiter plates for the yeast susceptibility tests were incubated at $25^{\circ} \mathrm{C}$ for $48 \mathrm{~h}$. Because the mold strain $A$. niger grows slowly, it was incubated at $25^{\circ} \mathrm{C}$ for $72 \mathrm{~h}$. The microtiter plates were analyzed by $\mathrm{OD}_{620}$ measure- 
ment (FLUOstar Omega, BMG Labtech, Ortenberg, Germany). Growth was defined by $\Delta \mathrm{OD}_{620} \geq 0.2$ compared to the negative control and the MIC was the lowest concentration resulting in $\Delta \mathrm{OD}_{620}<0.2$.

\subsection{Flow Cytometry Measurement of Antifungal Activity}

The antifungal susceptibility tests of S. cerevisiae and Z. bailii were complemented with flow cytometry measurements using a NovoCyte Flow Cytometer (Acea Biosciences, San Diego, CA, USA). Live/dead staining was performed with the fluorescent dye SYBR Green I (10,000 $\times$ concentrate in dimethyl sulfoxide (DMSO); Lonza Group, Basel, Switzerland) and propidium iodide (PI; $1 \mathrm{mg} / \mathrm{mL}$; Biotium, Fremont, CA, USA). To reduce background noise, the threshold value of the forward scatter was set to a lower limit of 10,000 (channel value). A photomultiplier with a band pass filter of 530/30 nm was used to collect the green fluorescence of SYBR, while the red fluorescence of PI was detected using a band pass filter of $660 / 20 \mathrm{~nm}$. For each sample, $20 \mu \mathrm{L}$ was collected at a flow rate of 3000 events per second. Analysis and gating of data were performed using the Novo Express software 1.2 (Acea Biosciences). Because a combination of forward scatter and sideward scatter was used to discriminate cells from the background, a species-specific gate for cell detection was defined. For the evaluation of viability, the gates were set manually and verified by running unstained, single-stained and dual-stained samples or negative controls containing no cells. Quadrants were associated with cell membrane integrity (intact: SYBR Green I positive but PI negative; not intact: both SYBR Green I and PI positive). Cell concentrations with and without intact cell membrane integrity were calculated from each sample volume as events in the respective gates. Flow cytometry measurements were performed in triplicates.

\subsection{Assays for Antioxidative Activity}

The antioxidative activity was tested in 96-well microtiter plates using the 2,2-diphenyl1-picrylhydrazyl (DPPH) assay according to Chen et al. [15] and the reducing power assay according to Chu et al. [16] with small modifications. After mixing $50 \mu \mathrm{L}$ of peptide solution with $50 \mu \mathrm{L}$ of DPPH ( $2 \mathrm{mM}$ solved in ethanol, Sigma-Aldrich), the sample was incubated overnight under light exclusion. Afterwards a microplate reader measured the absorption (A) at $515 \mathrm{~nm}$ monitoring the discoloration of purple to light yellow. A mixture of water and ethanol without DPPH was used as blank. The antioxidative activity in percent (scavenging activity) was calculated with the following equation:

$$
\text { Scavenging activity }(\%)=100-\frac{\left(\mathrm{A}_{\text {Sample }}-\mathrm{A}_{\text {Blank }}\right) \times 100}{\mathrm{~A}_{\text {neg.Control }}} \text {. }
$$

To quantify the reducing power, $50 \mu \mathrm{L}$ of the peptide solution was mixed with $50 \mu \mathrm{L}$ of phosphate buffer $(0.2 \mathrm{M}, \mathrm{pH}$ 6.6) and $50 \mu \mathrm{L}$ of $1 \%$ potassium ferricyanide solution (Merck, Darmstadt, Germany). The mixture was incubated for $20 \mathrm{~min}$ at $50{ }^{\circ} \mathrm{C}$, followed by the addition of $50 \mu \mathrm{L}$ of trichloroacetic acid (10\%, BioXtra, Sigma-Aldrich) and a centrifugation step $(857 \times g, 10 \mathrm{~min})$. The 96-well microtiter plate was prepared with $50 \mu \mathrm{L}$ each of sample mixture, water and $0.1 \%$ anhydrous ferric chloride solution (98\%, Sigma-Aldrich), incubated for $5 \mathrm{~h}$ in the dark and measured at $700 \mathrm{~nm}$ using a microplate reader. The reducing power (in percent) and, therefore, the formation of the Prussian blue complex was calculated as follows:

$$
\text { Reducing power }(\%)=100-\left(\mathrm{A}_{\text {neg.Control }} / \mathrm{A}_{\text {Sample }}\right) \times 100
$$

In both assays, water was used as negative and ascorbic acid as positive control. Peptides and positive control were tested in twofold dilution from 15.6 to $1000 \mu \mathrm{M}$. Additionally, the free amino acids tryptophan, tyrosine, histidine, cysteine, proline, and phenylalanine were tested using the same concentration range. The antioxidative activity was determined in triplicates and the experiments were repeated twice. 


\subsection{Cell Culture}

Human colorectal adenocarcinoma cells (Caco-2) were cultured in GlutaMax minimum essential medium maintained in $75 \mathrm{~cm}^{2}$ sterile flasks (Nunc EasyFlask, Thermo Fisher Scientific) at $37{ }^{\circ} \mathrm{C}$ in a saturated humidity atmosphere containing $5 \% \mathrm{CO}_{2}$ and $95 \%$ air. The medium was supplemented with $57 \mathrm{~mL}$ of fetal bovine serum (not inactivated, 10\%), $5.8 \mathrm{~mL}$ of sodium pyruvate $(100 \mathrm{mM}), 5.8 \mathrm{~mL}$ of nonessential amino acids $(100 \times)$ and $5.8 \mathrm{~mL}$ of penicillin $(10,000 \mathrm{IU}) /$ streptomycin $(10,000 \mu \mathrm{g} / \mathrm{mL}) /$ amphotericin B $(25 \mu \mathrm{g} / \mathrm{mL})$. The medium and all supplements for cell culture were obtained from Life Technologies (Darmstadt, Germany).

\subsection{MTT Cytotoxicity Assay}

The cytotoxicity of the test substances was assessed in the 3-(4,5-dimethylthiazol-2-yl)2,5-diphenyltetrazoliumbromid (MTT) assay [5]. Caco-2 cells were incubated with different concentrations of Leg1 $(7.8-2000 \mu \mathrm{M})$, Leg2 $(7.8-2000 \mu \mathrm{M})$, nisin $(7.8-2000 \mu \mathrm{M})$, sodium benzoate $(313-80,000 \mu \mathrm{M})$, potassium sorbate $(625-160,000 \mu \mathrm{M}$, Acros Organics, brand of Thermo Fisher Scientific), and sodium nitrite (156-40,000 $\mu \mathrm{M}$, Sigma-Aldrich). Water was used as negative and $10 \%$ DMSO as positive cytotoxic control. The negative control was set as 100\% cell viability and the cytotoxicity of the test substances was calculated referring to the negative control. Cytotoxicity was determined in triplicates.

\subsection{Statistical Analysis}

GraphPad PRISM 8 and OriginPro 2019 (OriginLab Corporation, Northampton, MA, USA) were used for statistical analysis. The results were depicted as the mean of triplicates \pm standard deviation. The results were compared to the negative control using one-way analysis of variance (ANOVA) with Tukey's Honest Significant Different (HSD) test for pairwise comparison (95\% confidence interval). The levels of significance were ${ }^{*} p<0.05$, ${ }^{* *} p<0.01,{ }^{* * *} p<0.001,{ }^{* * * *} p<0.0001$.

\section{Results and Discussion}

A previous study demonstrated the antibacterial activity of Leg1 and Leg2 against a wide range of food spoilage bacteria and food pathogens [5]. Based on the structure of these peptides and the reported mode of action of the antimicrobial effects, we hypothesized that Leg1 and Leg2 may show additional activity against food spoilage. In particular, we tested for cooperative activity with sodium benzoate and antifungal as well as antioxidative activities.

\subsection{Cooperative Effects of Leg1 and Leg2 with Sodium Benzoate on Bacterial Growth}

While antimicrobial agents with the same mechanism of action compete and lead to indifferent effects on antimicrobial activity, preservatives with different mechanisms of action may have at least additive or even synergistic impact. Organic acids like sodium benzoate or potassium sorbate are bacteriostatic agents. After passing the cell membrane in undissociated form, they dissociate inside the cell and inhibit bacterial growth by $\mathrm{pH}-$ induced stress [17]. In contrast, AMPs act as membrane-disrupting bactericidal agents that interact with the bacterial membrane and form pores eventually killing the bacteria [2] These pores may facilitate the entry of sodium benzoate into the cell and consequently lead to cooperative antimicrobial activity. To test for possible cooperative effects, we added the peptides Leg1 or Leg2 to the preservative sodium benzoate and determined the antimicrobial effects of all pairings against $E$. coli and B. subtilis in a checkerboard assay measuring the $\mathrm{OD}_{570}$ (Figure 2). In combination with Leg1 and Leg2, the MIC values of sodium benzoate against $E$. coli and B. subtilis were considerably lower indeed. For example, $31.3 \mu \mathrm{M}$ Leg1/Leg2 reduced the MIC value of sodium benzoate against $E$. coli by a factor of eight. 
A

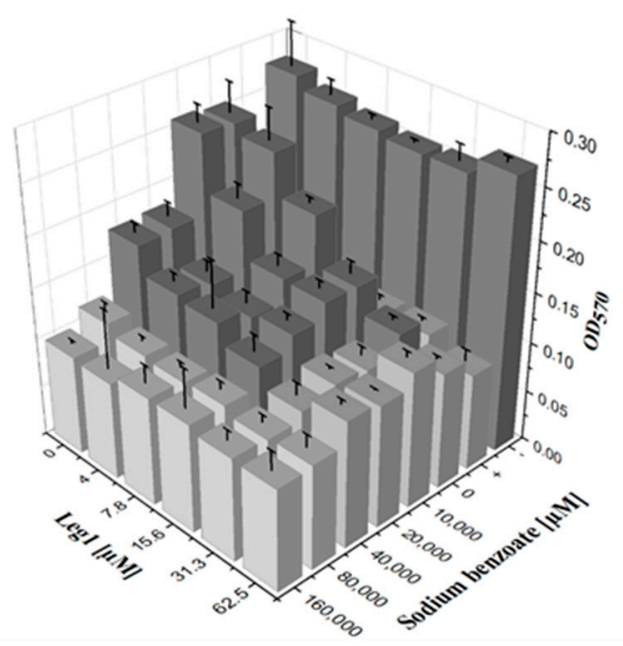

C

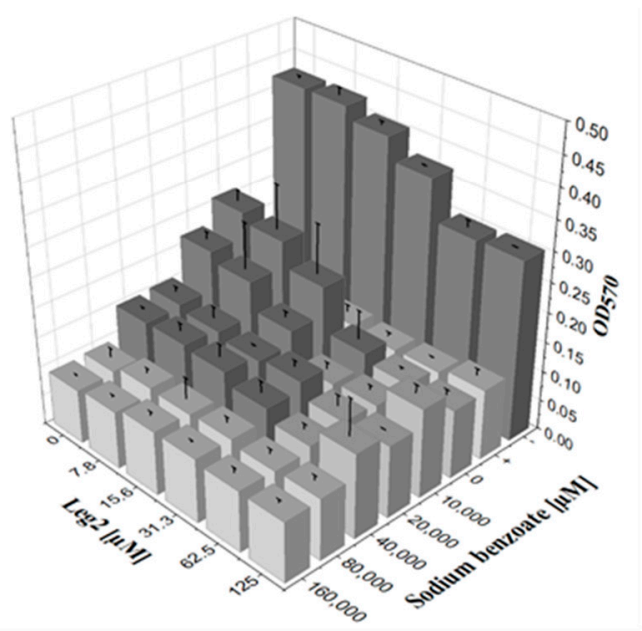

B

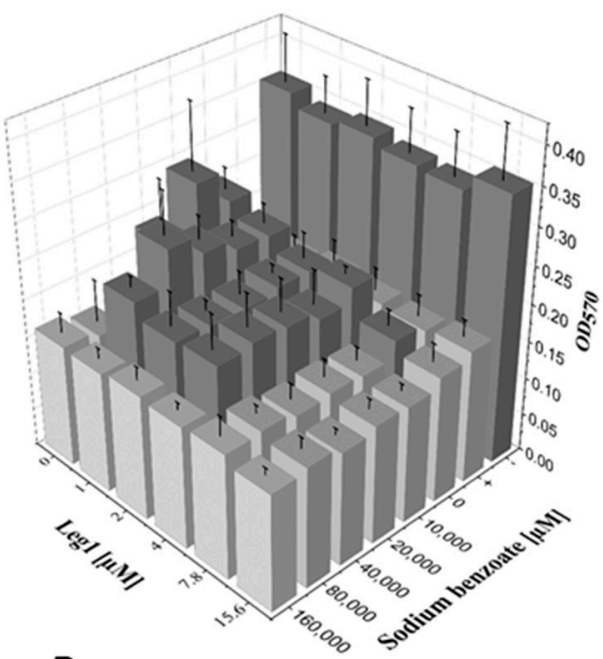

D

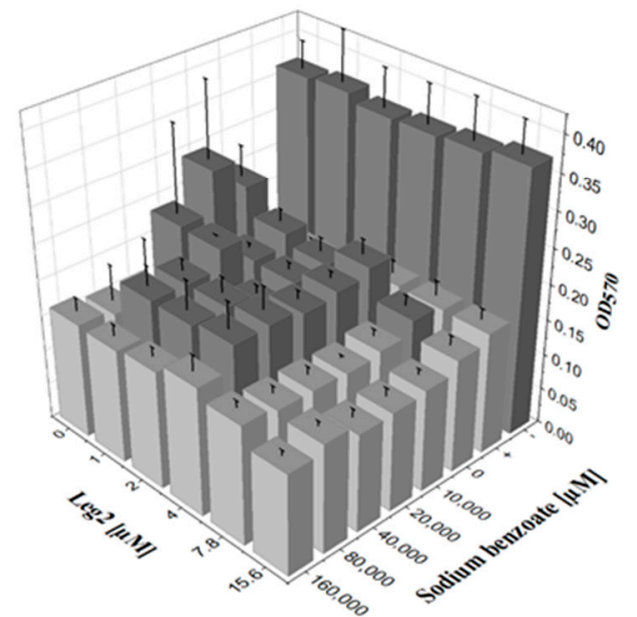

Figure 2. Results of a checkerboard assay using Leg1 or Leg2 combined with sodium benzoate against (A,C) E. coli and (B,D) B. subtilis to determine the fractional inhibitory concentration (FIC) indices. Water was used as negative control (-) and ampicillin (+) as positive control. The optical density is displayed as mean \pm SD of triplicates measured at $570 \mathrm{~nm}$. Bacterial growth is indicated in dark grey.

To quantify combinatorial effects of Leg1 and Leg2 with sodium benzoate, the FIC index was calculated. FIC values of 0.625 for E. coli (Table 1 ) and 0.75 for B. subtilis (Table 2) imply strong additive effects in all combinations. The results were very similar to the cooperative activity of nisin, which was tested in the same way as Leg1 and Leg2 (Tables 1 and 2) indicating a general cooperative mechanism of AMPs and sodium benzoate.

Table 1. Results of the checkerboard assay of Leg1/Leg2/nisin and sodium benzoate (SB) against E. coli displaying $\mathrm{MIC}_{\mathrm{A}} / \mathrm{MIC}_{\mathrm{B}}$ (MIC for the peptide or $\mathrm{SB}$ ), $\mathrm{MIC}_{\mathrm{AB}} / \mathrm{MIC}_{\mathrm{BA}}$ (MIC for the combination of peptide and $\mathrm{SB}$ ) and fractional inhibitory concentration (FIC) values.

\begin{tabular}{cccc}
\hline Peptide & $\mathbf{M I C}_{\mathbf{A}} / \mathbf{M I C}_{\mathbf{A B}}$ (Peptide) $[\boldsymbol{\mu M}]$ & $\mathbf{M I C}_{\mathbf{B}} / \mathbf{M I C}_{\mathbf{B A}}(\mathbf{S B})[\boldsymbol{\mu M}]$ & FIC $^{\mathbf{1}}$ \\
\hline Leg1 & $62.5 / 31.3$ & $80,000 / 10,000$ & 0.625 \\
Leg2 & $62.5 / 31.3$ & $80,000 / 10,000$ & 0.625 \\
Nisin & $125 / 15.6$ & $80,000 / 40,000$ & 0.625 \\
\hline
\end{tabular}

${ }^{1}$ FIC $<0.5$ interpreted as synergy, $0.5<$ FIC $>2.0$ as additivity, $2.0<$ FIC $>4.0$ as indifference and FIC $>4.0$ as antagonism. 
Table 2. Results of the checkerboard assay of Leg1/Leg2/nisin and sodium benzoate (SB) against B. subtilis displaying $\mathrm{MIC}_{\mathrm{A}} / \mathrm{MIC}_{\mathrm{B}}$ (MIC for the peptide or $\mathrm{SB}$ ), $\mathrm{MIC}_{\mathrm{AB}} / \mathrm{MIC}_{\mathrm{BA}}$ (MIC for the combination of peptide and $\mathrm{SB}$ ) and fractional inhibitory concentration (FIC) values.

\begin{tabular}{cccc}
\hline Peptide & $\mathbf{M I C}_{\mathbf{A}} / \mathbf{M I C}_{\mathrm{AB}}($ Peptide) $[\boldsymbol{\mu M}]$ & $\mathbf{M I C}_{\mathbf{B}} / \mathbf{M I C}_{\mathbf{B A}}(\mathbf{S B})[\boldsymbol{\mu M}]$ & FIC $^{\mathbf{1}}$ \\
\hline Leg1 & $15.6 / 7.8$ & $80,000 / 10,000$ & 0.75 \\
Leg2 & $15.6 / 7.8$ & $80,000 / 10,000$ & 0.75 \\
Nisin & $7.8 / 2.0$ & $80,000 / 40,000$ & 0.75 \\
\hline
\end{tabular}

${ }^{1}$ FIC $<0.5$ interpreted as synergy, $0.5<$ FIC $>2.0$ as additivity, $2.0<$ FIC $>4.0$ as indifference and FIC $>4.0$ as antagonism.

Previous studies demonstrated that other AMPs acted synergistically/additively in combination with conventional antibiotics [18,19]. Additionally, Lòpez-Expòsito et al. showed similar effects for milk peptides in combination with the preservative peptide nisin against Gram-positive bacterial strains (Listeria monocytogenes and Staphylococcus epidermidis) [20]. Whereas Stanojevic et al. observed indifferent activity against most bacterial strains by the combined preservatives sodium benzoate and potassium sorbate, the combination of these organic acids with sodium nitrite had synergistic effects [21]. The simultaneous application of the antimicrobial peptides Leg1/Leg2 with conventional preservatives, such as sodium benzoate, may allow reducing their dose and may address a wider spectrum of microorganisms.

\subsection{Antifungal Activity of Leg1 and Leg2}

The composition of fungal cell membranes differs fundamentally from bacterial membranes [22]. Therefore, the efficacy of cell-penetrating antimicrobial peptides against bacteria cannot be easily extrapolated to fungi. In order to determine the activity of Leg1 and Leg2 against fungi, a microdilution assay was applied. Both peptides showed fungistatic activity against $S$. cerevisiae and $Z$. bailii, but not against $P$. membranifaciens or A. niger (Supplementary Materials, Tables S1 and S2). In addition, flow cytometry analysis was performed to confirm the fungistatic effects of Leg1 and Leg2 against S. cerevisiae and Z. bailii and to differentiate fungistatic, fungicidal, or fungilytic modes of action of both peptides. Fungistatic agents inhibit the cell division [23], whereas fungicidal agents cause cell death [24], which can be distinguished by fluorometric staining. Flow cytometry determined fungistatic effects of Leg1 and Leg2 against S. cerevisiae and Z. bailii; Leg2 had lower MIC values $(250 \mu \mathrm{M}$ and $125 \mu \mathrm{M})$ than Leg1 $(500 \mu \mathrm{M}$ and $250 \mu \mathrm{M})$. Both AMPs also showed fungicidal effects indicated by lower cell numbers than the inoculum concentration. In general, the fungicidal effect was more pronounced against $Z$. bailii than S. cerevisiae. Even at concentrations below MIC, Leg1/Leg2 significantly reduced the number of yeast cells compared to the controls (Figures 3 and 4).

Leg1 and Leg2 are probably membrane-active peptides [5] and the variations in antifungal activity might be caused by different architectures of the cell envelope, which is crucial for cell viability, morphology and protection against stressors like AMPs. Fungal cell walls have multifaceted composition and organization and are mainly composed of glucans, chitin, and glycoproteins [25]. The cell walls of the filamentous fungi Aspergillus spp. have a higher chitin content than those of S. cerevisiae and contain high amounts of melanin, which contribute to fungal virulence [26,27]. Grillitsch et al. observed clear differences in the cell membrane structure, for example, the degree of fatty acid saturation and ergosterol levels of P. pastoris compared to S. cerevisiae [28], which could be the reason why Leg1 and Leg2 had no antifungal effect against P. membranifaciens. In contrast, S. cerevisiae and $Z$. bailii both belong to the family Saccharomycetaceae and have high phylogenetic correlation and a high percentage of identical gene sequences [29,30]. Additionally, Nguyen et al. reported a similar general composition of the cell wall of Z. bailii and S. cerevisiae containing mannoprotein (24-35\%), chitin (0.6-3\%), alkali-soluble (34-37\%) and alkali-insoluble glucan $(20-37 \%)$ [31]. 
A

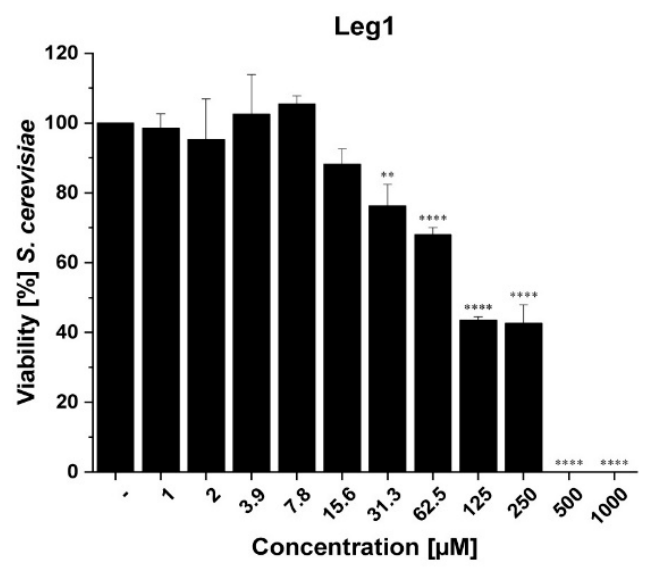

C

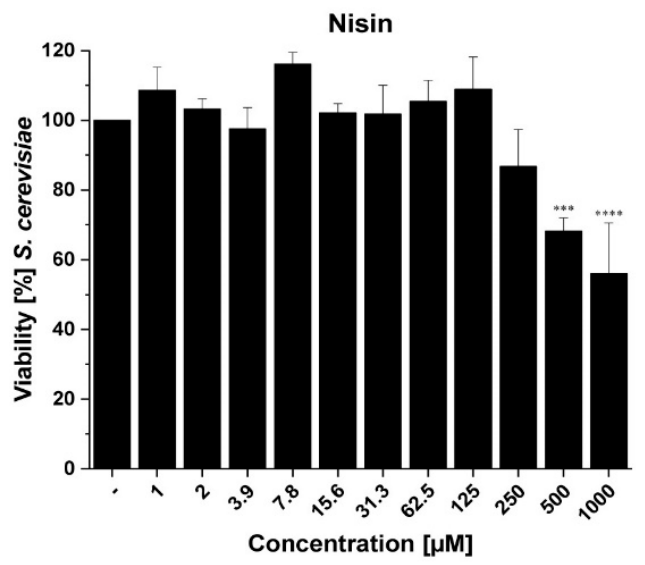

B

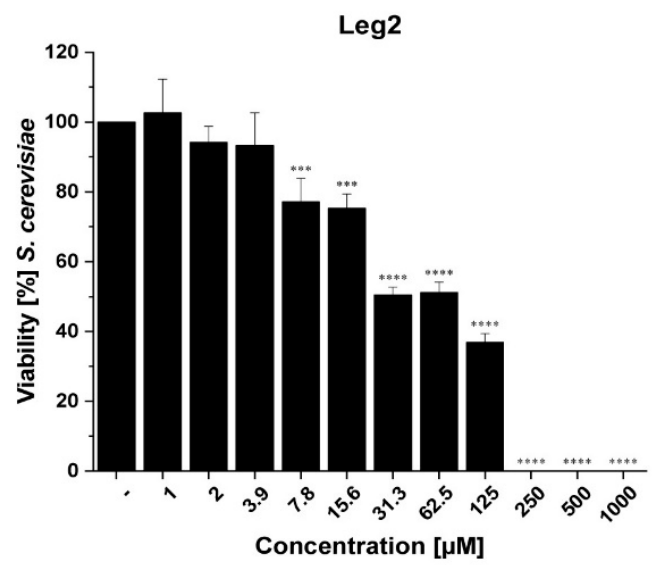

D

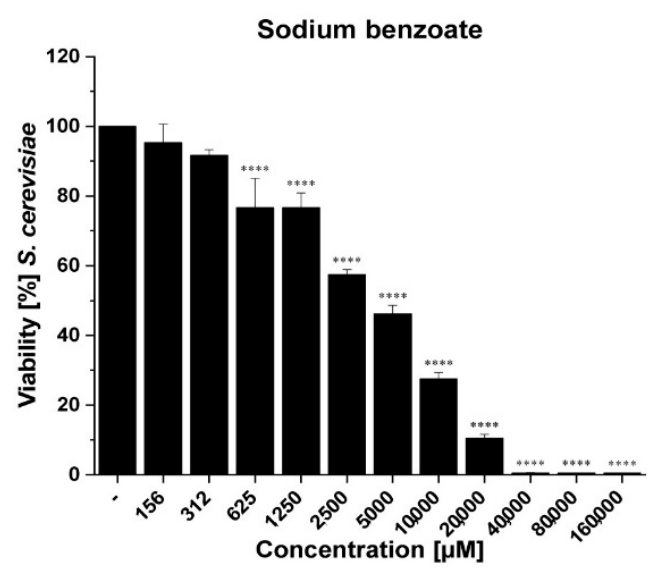

Figure 3. Results of the flow cytometry measurement of antifungal activity using (A) Leg1, (B) Leg2, (C) nisin, and (D) sodium benzoate against $S$. cerevisiae. Water $(-)$ was used as negative control. Viability (as mean \pm SD of triplicates) is expressed as percentage in relation to the negative control. The levels of significance were ${ }^{* *} p<0.01,{ }^{* * *} p<0.001$, $* * * * 00.0001$.

The present results demonstrate antifungal effects of the AMPs Leg1 and Leg2 against members of the family Saccharomycetaceae, but not the families Pichiaceae or Trichocomaceae. For comparison, sodium benzoate, a common weak-acid preservative with fungistatic effects [32] and nisin were included in the present study. Nisin is known for its antimicrobial effect against a number of Gram-positive bacteria and also for inhibiting the outgrowth of spores [33]. In general, nisin has no inhibitory effect on yeasts and filamentous fungi, but Dielbandhoesing et al. showed that $S$. cerevisiae is sensitive against nisin in certain stages of the cell cycle [34]. Nisin significantly reduced the cell numbers of both S. cerevisiae and Z. bailii, but had no fungicidal effect (Figures 3 and 4). Fungistatic effects on both strains were found after treatment with high concentrations of sodium benzoate (S. cerevisiae, $40,000 \mu \mathrm{M} ; \mathrm{Z}$. bailii, $160,000 \mu \mathrm{M})$. This result is not surprising because Z. bailii is known to be very resistant to weak-acid preservatives [10].

In concentrations $\geq 125 \mu \mathrm{M}$ (Leg1) and $\geq 62.5 \mu \mathrm{M}$ (Leg2), blank controls of Leg1 and Leg2 without inoculum showed a concentration-dependent increase of $\mathrm{OD}_{620}$ values in the microdilution assay (Supplementary Materials, Figure S1). However, no elevated $\mathrm{OD}_{620}$ values were observed in other assays such as the antimicrobial assay, so that matrix-specific peptide aggregation can be assumed, dependent on the $\mathrm{pH}$ or matrix components [35-38]. Further studies are required to determine if the observed antifungal susceptibility is dependent on the peptide aggregation. 
A

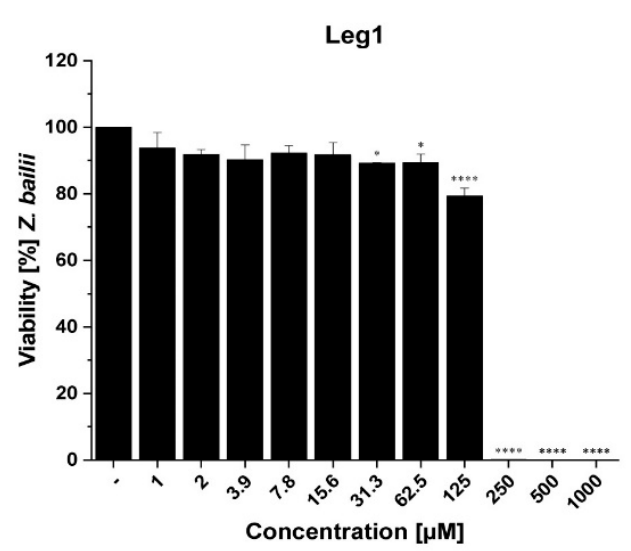

C

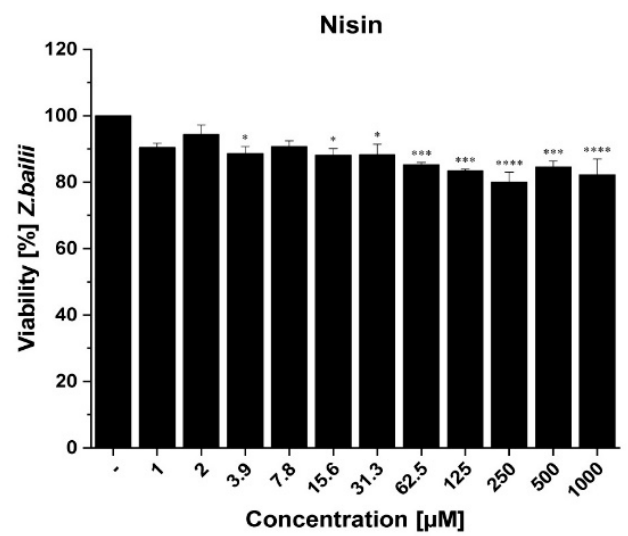

B

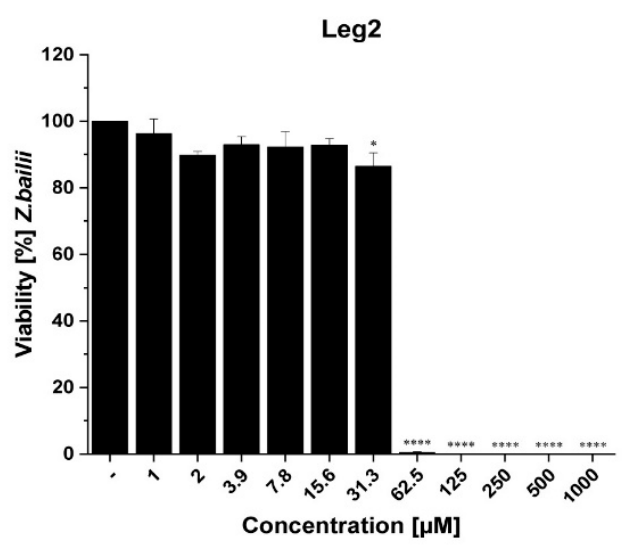

D

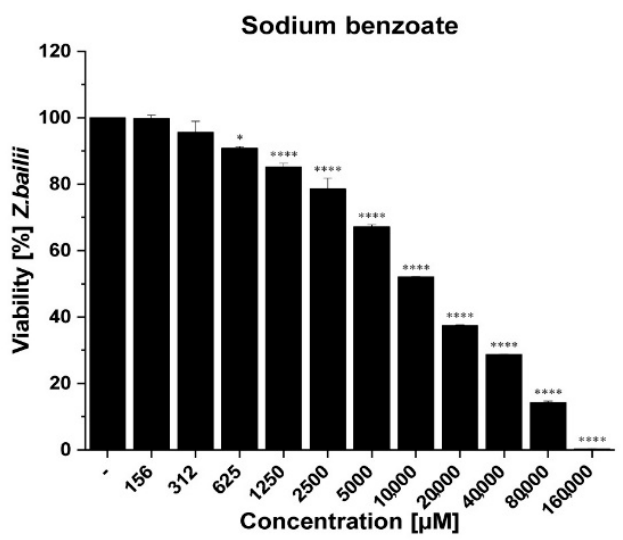

Figure 4. Results of flow cytometry measurements of antifungal activity using (A) Leg1, (B) Leg2, (C) nisin, and (D) sodium benzoate against Z. bailii. Water (-) was used as negative control. Viability (as mean \pm SD of triplicates) is expressed as percentage in relation to the negative control. The levels of significance were ${ }^{*} p<0.05,{ }^{* * *} p<0.001,{ }^{* * *} p<0.0001$.

\subsection{Antioxidative Activity of Leg1/Leg2}

Besides bacterial and fungal activity, oxidation reactions are a common cause of food spoilage. Many peptides have antioxidative properties, particularly if they contain antioxidant amino acids; the present study examined therefore possible antioxidative effects of Leg1 and Leg2 in radical scavenging- (DPPH) and reducing-power assays. Tryptophan, phenylalanine, and proline are part of the Leg1 and Leg2 sequences and have antioxidative properties. Therefore, the assay covered these single amino acids to evaluate their contribution to the activity of the peptides. Additionally, the antioxidative amino acids histidine, cysteine, and tyrosine [39] were included for comparison and as further positive controls. Table 3 displays the radical scavenging activity of Leg1/Leg2 and the selected single amino acids. High concentrations of Leg2 (500 $\mu \mathrm{M}, 1000 \mu \mathrm{M})$ showed an antioxidative activity of about $91.5-72.2 \%$. The activity decreased dose-dependently down to $5.3 \%$ at a concentration of $15.6 \mu \mathrm{M}$. At the higher concentrations, the antioxidative impact of Leg2 was in the same range as the effects of ascorbic acid and the most active amino acids tyrosine and cysteine. In the lower concentration range, Leg2 was less active than ascorbic acid, tyrosine, and cysteine, but still more active than histidine. With a maximum activity of about $29.3 \%$, Leg1 acted as a weak radical scavenger. Aromatic amino acids like phenylalanine and tryptophan act as radical scavenger by donating hydrogens or electrons to electron-deficient radicals. The single amino acid tryptophan had 60.8-17.6\% scavenging activity, whereas phenylalanine reached only $22.8 \%$. Because Leg2 differs from Leg1 solely in the exchange of phenylalanine by tryptophan, the increased antioxidative activity of Leg2 can be attributed to tryptophan. However, Leg2 showed a higher activity 
compared to tryptophan alone. Therefore, the other hydrophobic amino acids, such as proline, alanine, leucine, isoleucine or effects by the neighboring amino acids are likely to play an additional role.

Table 3. Results of the antioxidant DPPH assay using Leg1/Leg2 and single amino acids in a concentration range of 15.6-1000 $\mu \mathrm{M}$. Ascorbic acid was used as positive control. The mean \pm SD of triplicates of the antioxidative activity is displayed.

\begin{tabular}{|c|c|c|c|c|c|c|c|}
\hline \multirow{2}{*}{ Concentration $[\mu \mathrm{M}]$} & \multicolumn{7}{|c|}{ Antioxidant Activity (\%) } \\
\hline & 1000 & 500 & 250 & 125 & 62.5 & 31.3 & 15.6 \\
\hline $\begin{array}{c}\text { Leg1 } \\
\text { (RIKTVTSFDLPALRFLKL) }\end{array}$ & $29.3 \pm 3.7$ & $6.0 \pm 8.2$ & $0.30 \pm 0.5$ & -1 & - & - & - \\
\hline $\begin{array}{c}\text { Leg2 } \\
\text { (RIKTVTSFDLPALRWLKL) }\end{array}$ & $91.5 \pm 8.3$ & $72.2 \pm 12.8$ & $46.2 \pm 16.6$ & $20.9 \pm 22.6$ & $26.7 \pm 1.3$ & $17.7 \pm 2.3$ & $5.3 \pm 3.3$ \\
\hline Tyrosine & $50.3 \pm 6.0$ & $52.4 \pm 4.5$ & $42.3 \pm 11.6$ & $31.2 \pm 4.5$ & $40.1 \pm 7.5$ & $10.4 \pm 12.2$ & - \\
\hline Histidine & $34.5 \pm 9.1$ & $32.8 \pm 7.3$ & $30.0 \pm 3.2$ & $17.9 \pm 11.9$ & $19.1 \pm 3.7$ & $6.1 \pm 4.0$ & $0.2 \pm 6.4$ \\
\hline Cysteine & $93.6 \pm 1.9$ & $82.6 \pm 8.9$ & $95.7 \pm 1.5$ & $94.1 \pm 2.2$ & $90.2 \pm 8.8$ & $88.5 \pm 7.2$ & $72.8 \pm 11.6$ \\
\hline Tryptophan & $60.8 \pm 11.1$ & $38.6 \pm 2.5$ & $22.8 \pm 4.4$ & $15.2 \pm 7.9$ & $17.9 \pm 5.8$ & $19.5 \pm 5.6$ & $17.6 \pm 5.7$ \\
\hline Proline & $28.7 \pm 9.4$ & $25.6 \pm 10.9$ & $23.3 \pm 5.9$ & $19.0 \pm 11.6$ & $8.5 \pm 8.5$ & - & - \\
\hline Phenylalanine & $29.0 \pm 6.2$ & $20.5 \pm 3.9$ & $18.1 \pm 8.4$ & $19.3 \pm 14.2$ & $10.6 \pm 6.4$ & - & - \\
\hline Ascorbic acid & $91.2 \pm 2.4$ & $82.2 \pm 8.2$ & $74.3 \pm 13.2$ & $79.2 \pm 15.4$ & $70.1 \pm 4.2$ & $71.9 \pm 6.9$ & $58.9 \pm 1.9$ \\
\hline
\end{tabular}

The results of the ferric reducing assay (Table 4) confirmed the strong antioxidative activity of Leg2 observed by the radical scavenging assay. With a maximum activity of $86.3 \%$, the reducing power of Leg2 was only slightly lower than the effect of ascorbic acid (maximum 94.7\%) and similar to cysteine, tyrosine and histidine (maxima 90.2\%, 87.1\% and $85.4 \%$ ) throughout the whole concentration range.

Table 4. Results of the reducing power assay using Leg1/Leg2 and single amino acids in a concentration range of 15.6-1000 $\mu \mathrm{M}$. Ascorbic acid was used as the positive control. The mean $\pm \mathrm{SD}$ of triplicates of the antioxidative activity is displayed.

\begin{tabular}{|c|c|c|c|c|c|c|c|}
\hline \multirow{2}{*}{ Concentration $[\mu \mathrm{M}]$} & \multicolumn{7}{|c|}{ Antioxidant Activity (\%) } \\
\hline & 1000 & 500 & 250 & 125 & 62.5 & 31.3 & 15.6 \\
\hline $\begin{array}{c}\text { Leg1 } \\
\text { (RIKTVTSFDLPALRFLKL) }\end{array}$ & $70.3 \pm 2.2$ & $64.7 \pm 3.0$ & $56.3 \pm 2.2$ & $42.6 \pm 3.0$ & $26.0 \pm 2.5$ & $19.3 \pm 1.4$ & $8.3 \pm 1.8$ \\
\hline $\begin{array}{c}\text { Leg2 } \\
\text { (RIKTVTSFDLPALRWLKL) }\end{array}$ & $86.3 \pm 2.2$ & $84.2 \pm 3.3$ & $79.5 \pm 0.3$ & $60.2 \pm 2.4$ & $52.4 \pm 2.8$ & $30.0 \pm 1.7$ & $20.3 \pm 10.2$ \\
\hline Tyrosine & $87.1 \pm 0.7$ & $82.7 \pm 0.7$ & $75.1 \pm 0.8$ & $57.1 \pm 1.9$ & $40.9 \pm 8.0$ & $14.6 \pm 2.8$ & $11.1 \pm 1.0$ \\
\hline Histidine & $85.4 \pm 5.7$ & $81.1 \pm 0.9$ & $30.0 \pm 6.3$ & $17.3 \pm 3.2$ & $19.0 \pm 7.0$ & $6.1 \pm 2.6$ & -1 \\
\hline Cysteine & $90.2 \pm 0.1$ & $83.5 \pm 0.1$ & $75.4 \pm 0.3$ & $62.6 \pm 0.4$ & $47.5 \pm 0.5$ & $32.0 \pm 1.8$ & $20.0 \pm 1.4$ \\
\hline Tryptophan & $92.7 \pm 0.3$ & $88.2 \pm 1.0$ & $82.2 \pm 1.9$ & $69.9 \pm 5.4$ & $55.7 \pm 6.9$ & $24.7 \pm 6.2$ & $10.8 \pm 10.7$ \\
\hline Proline & $12.2 \pm 4.2$ & $28.2 \pm 5.2$ & $1.7 \pm 4.8$ & $33.6 \pm 4.9$ & $14.3 \pm 1.3$ & - & - \\
\hline Phenylalanine & $22.8 \pm 2.9$ & $19.7 \pm 0.5$ & $14.1 \pm 1.1$ & $2.7 \pm 3.1$ & - & - & - \\
\hline Ascorbic acid & $94.7 \pm 0.1$ & $92.0 \pm 0.3$ & $83.6 \pm 0.6$ & $74.6 \pm 0.4$ & $60.2 \pm 1.7$ & $40.8 \pm 2.1$ & $28.4 \pm 0.9$ \\
\hline
\end{tabular}

In contrast to its low radical scavenging activity, Leg1 showed also notable reducing activity with a maximum of about $70.3 \%$ indicating that Leg1 may contribute to the antiox- 
idative activity by reducing rather than radical scavenging mechanisms. In the reducing assay, tryptophan was also more active than phenylalanine. This finding is in accordance with the literature [40] and may explain the stronger effects of Leg2 compared to Leg1. The reducing activities of Leg2 and tryptophan (maximum 92.7\%) are comparable suggesting that this amino acid is mainly responsible for the effect of Leg2. In contrast, Leg1 shows a higher activity compared to the single amino acid phenylalanine (maximum $22.8 \%$ ).

The presence of hydrophobic amino acids and especially aromatic amino acids (tryptophan, tyrosine, phenylalanine) can be the main determinant of the antioxidative activity of peptides [39]. Additionally, the indole ring of tryptophan acts as a strong hydroxyl radical scavenger. The higher reducing activity of Leg1 compared to phenylalanine can be explained by cooperative effects of other amino acids, although this phenomenon is not fully understood. For example, Ayala-Niño et al. showed that the presence of tryptophan in peptides is responsible for their radical trapping activity, which can be enhanced by a neighboring arginine [41]. Additionally, the presence of leucine and proline can increase the antioxidative activity by enhancing the hydrophobicity [42]. Thus, the presence of leucine and isoleucine in Leg1and Leg2 may further promote the reducing power of the peptide [43]. Structure-activity relationships were examined in the past addressing, for example, the position of an amino acid in the sequence (c-terminal, n-terminal), the presence of functional groups or the molecular weight [44,45]. However, synergistic effects between amino acids or the influence of the tertiary structure are hardly elucidated, so that the behavior of different sequences in various test assays cannot be predicted yet. Recently, a good correlation between the radical scavenging activity and reducing activity of ovalbumin hydrolysates was reported [46].

Because the antimicrobial peptides Leg1 and especially Leg2 showed antioxidative activity, these peptides could simultaneously protect foods against microbial and oxidative deterioration. Utilizing Leg 1 and Leg 2 as preservatives may thus additionally prevent fat rancidity and color changes. A combined antioxidative and antimicrobial activity was reported for peptide fractions of string beans, whereas the fungus Candida albicans was not sensitive [47].

\subsection{Cytotoxicity against Caco-2 Cells}

Molecular dynamics simulations attributed the antimicrobial activity of Leg1 and Leg2 to a specific deterioration of the bacterial membrane [5]. The observed antifungal activity may result from a different mechanism, because bacterial and fungal cell membranes differ in structures and compositions. Therefore, an unspecific interaction with different membrane types cannot be excluded, which would imply that Leg1 and Leg2 could have cytotoxic effects against human cells. To assess possible cytotoxic activity, the effect of Leg1 and Leg2 on the viability of human Caco-2 cells was tested in a MTT assay. Local cytotoxic effects of food-derived AMPs in the gastro-intestinal tract are probably more relevant than systemic activity. Therefore, Caco-2-cells were used to determine cytotoxicity, because they originate from the human colon and are often used as a model for the intestinal barrier [48]. For comparison, the approved preservatives sodium benzoate, potassium sorbate, sodium nitrite, and nisin were included in the assay. The test concentration ranges were selected based on the MIC values of the compounds against E. coli and B. subtilis [5]. Figure 5 displays the results of the MTT assay after an incubation time of $16 \mathrm{~h}$.

According to ISO 10993-5, cytotoxicity is defined by a cell viability $<70 \%$ compared to the control [49]. Thus, Leg1 was not cytotoxic in any of the applied concentrations, whereas only the highest concentration of Leg $2(2000 \mu \mathrm{M})$ showed a cytotoxic effect with $62 \%$ cell viability. In contrast, nisin led to a cell viability $<70 \%$ and therefore cytotoxic effects at $1000 \mu \mathrm{M}$ and $2000 \mu \mathrm{M}$. Sodium benzoate reduced the cell viability at $40,000 \mu \mathrm{M}$, potassium sorbate at $10,000 \mu \mathrm{M}$, and sodium nitrite at $625 \mu \mathrm{M}$. Thus, the present MTT assay confirmed that Leg1/Leg2 did not interfere with the cell viability of human colon cells in concentrations around the MIC of $62.5 \mu \mathrm{M}$ against $E$. coli as reported before [5] and of $15.6 \mu \mathrm{M}$ against B. subtilis. Furthermore, no cytotoxic effects were observed at the MICs 
of potassium sorbate $(40,000 \mu \mathrm{M}$ against E. coli, $80,000 \mu \mathrm{M}$ against $B$. subtilis $)$ and sodium nitrite $(20,000 \mu \mathrm{M}$ against $E$. coli, 40,000 $\mu \mathrm{M}$ against $B$. subtilis), whereas sodium benzoate was cytotoxic at its MIC (40,000 $\mu \mathrm{M}$ against E. coli).

A

Leg1

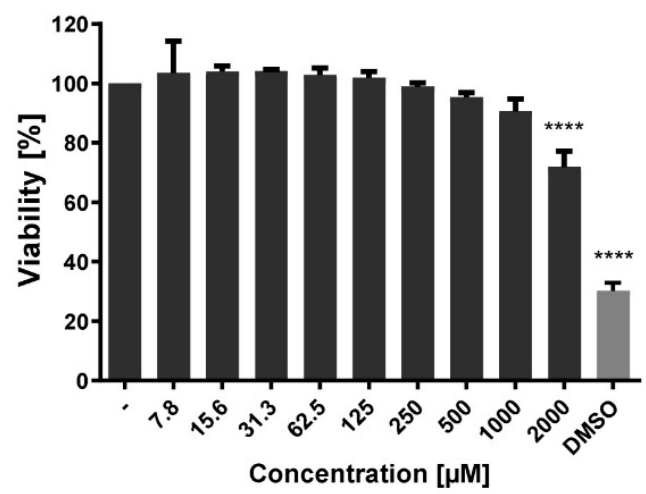

C

Nisin

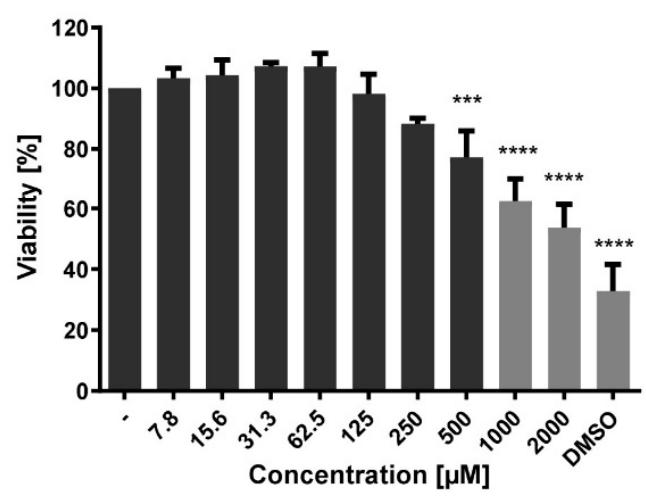

E

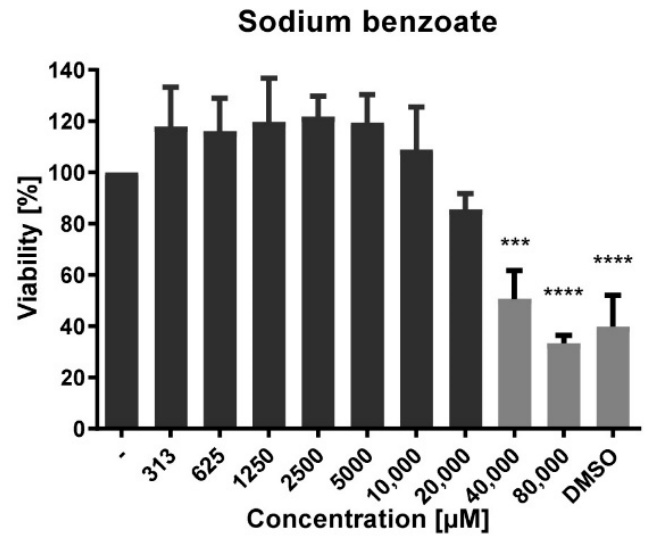

B

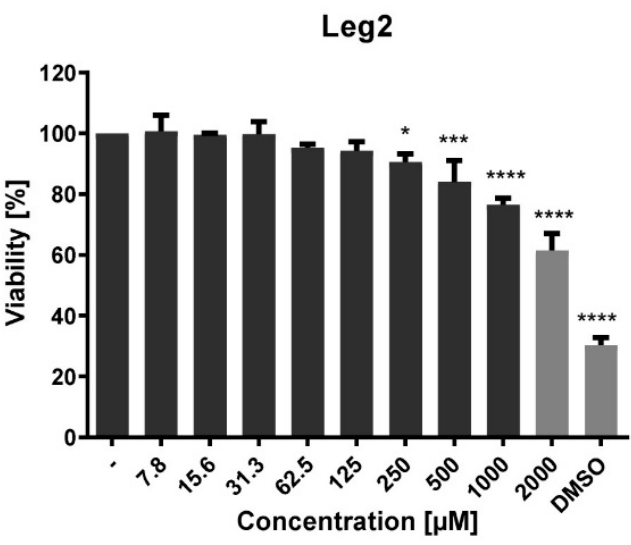

D

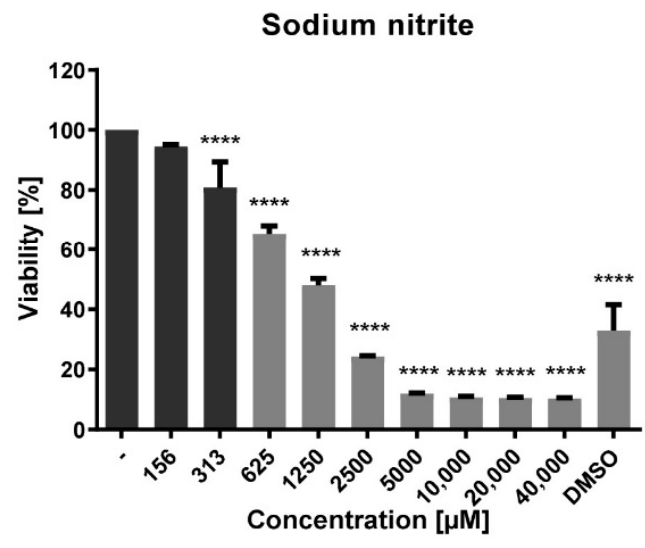

$\mathbf{F}$

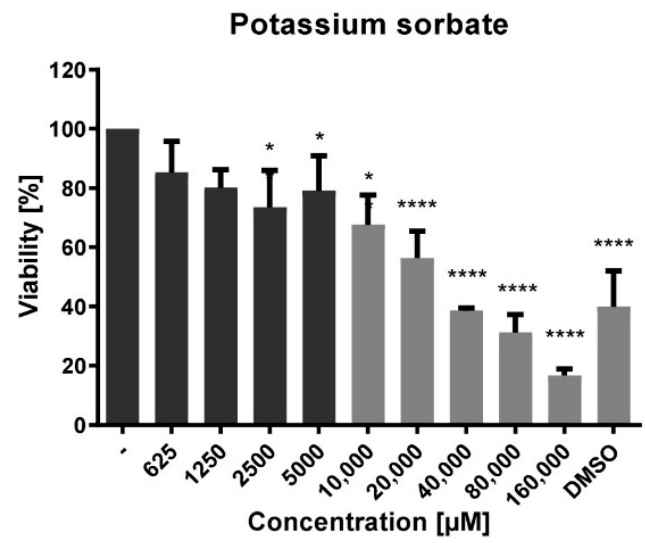

Figure 5. Influence of (A) Leg1, (B) Leg2, (C) nisin, (D) sodium nitrite, (E) sodium benzoate, and (F) potassium sorbate on the viability of Caco-2 cells as determined by the MTT assay. Water (-) was used as negative control and $10 \%$ DMSO as positive control. Viability (as mean $\pm \mathrm{SD}$ of triplicates) is expressed as percentage in relation to the negative control. Cytotoxic effects (viability $<70 \%$ ) are highlighted in light gray. The levels of significance were ${ }^{*} p<0.05,{ }^{* * *} p<0.001$, $* * * * p<0.0001$. 
So far, the observed MIC values were determined under optimal conditions for bacterial growth [5]. Under actual food storage conditions, when, for example, low temperatures or low oxygen levels pose an additional hurdle for bacterial growth, lower AMP concentrations can be effective. Therefore, the gaps between cytotoxic doses and the applied concentrations in food are probably even larger.

In case of nisin, previous studies determined cytotoxic effects at $298 \mu \mathrm{M}$ after $4 \mathrm{~h}$ against colon cancer cells [50], at $150 \mu \mathrm{M}$ after $1 \mathrm{~h}$ against melanoma cells [51] and at $7.5 \mu \mathrm{M}$ after $24 \mathrm{~h}$ against astrocytoma cells [52]. Vaucher et al. described the cytotoxic activity of the antimicrobial peptide P40, which was comparable to nisin [53]. The low cytotoxicity of Leg1 and Leg2 against human Caco-2 cells indicates a very specific interaction of both AMPs with the bacterial membrane. This observation is in very good accordance with recently reported molecular dynamics simulations [5], which showed specific binding of Leg2 through interactions between the acyl chains of the bacterial membrane and the hydrophobic side chains of the peptide. Zhao et al. obtained similar results in molecular dynamics simulations predicting stronger interaction of the antimicrobial peptides LL-37 with bacterial membranes than with mammalian membranes [54]. In comparison to the peptide nisin, which is approved for food preservation, Leg1 and Leg2 ensured higher cell viability. Cytotoxic effects, if any, of Leg1/Leg2 were only observed at high concentrations. Therefore, the AMPs are nontoxic to a human cell line, which is an important prerequisite for the application of Leg1 and Leg2 as food preservatives.

\section{Conclusions}

In summary, the present study revealed additional beneficial properties of the known antimicrobial peptides Leg1 and Leg2 for a potential application as food preservatives. Thus, strong additive effects in combination with the preservative sodium benzoate may enable to reduce effective doses. Additionally, both AMPs inhibited the growth of two foodspoilage yeast strains. Moreover, especially Leg2 showed antioxidative effects by radical scavenging and reducing activity. Thus, the application of the plurifunctional peptides Leg1 and Leg2 may simultaneously hinder bacterial, fungal and oxidative mechanisms of food spoilage. Further studies are now required to test the activity and stability of Leg1 and Leg2 during food storage.

Supplementary Materials: The following are available online at https://www.mdpi.com/2304-8 158/10/3/585/s1, Table S1: Antifungal susceptibility tests of Leg1, Leg2 and nisin against A. niger using a microdilution assay; Table S2: Antifungal susceptibility tests of Leg1, Leg2 and nisin against $P$. membranifaciens using a microdilution assay; Figure S1: $\mathrm{OD}_{620}$ values of the blank controls consisting of water, YM and different concentrations of Leg1 or Leg2 $(1-1000 \mu \mathrm{M})$.

Author Contributions: Conceptualization, M.-L.H., L.N., M.N. and M.P.; methodology, M.-L.H., L.N., D.H., M.N. and M.P.; validation, M.-L.H. and L.N.; formal analysis, M.-L.H. and L.N.; investigation, M.-L.H. and L.N.; resources, M.N. and M.P.; data curation, M.-L.H. and L.N.; writing-original draft preparation, M.-L.H., L.N. and D.H.; writing-review and editing, M.N. and M.P.; visualization, M.-L.H. and L.N.; supervision, M.N. and M.P.; project administration, M.-L.H., L.N., M.N. and M.P.; funding acquisition, M.N. and M.P. All authors have read and agreed to the published version of the manuscript.

Funding: This research was funded by ADALBERT RAPS FOUNDATION, Kulmbach, Germany.

Institutional Review Board Statement: Not applicable.

Informed Consent Statement: Not applicable.

Data Availability Statement: Data available on request.

Acknowledgments: We thank Christine Meissner for proofreading the manuscript.

Conflicts of Interest: The authors declare no conflict of interest. The funders had no role in the design of the study; in the collection, analyses, or interpretation of data; in the writing of the manuscript, or in the decision to publish the results. 


\section{References}

1. Dalabasmaz, S.; Pischetsrieder, M. Peptidomics in Food. In Comprehensive Foodomics; Cifuentes, A., Ed.; Elsevier: Cambridge, MA, USA, 2021; pp. 651-665.

2. Zasloff, M. Antimicrobial Peptides of Multicellular Organisms. Nature 2002, 415, 389-395. [CrossRef]

3. Bruno, B.J.; Miller, G.D.; Lim, C.S. Basics and Recent Advances in Peptide and Protein Drug Delivery. Ther. Deliv. 2013, 4, 1443-1467. [CrossRef]

4. Rai, M.; Pandit, R.; Gaikwad, S.; Kovics, G. Antimicrobial Peptides as Natural Bio-Preservative to Enhance the Shelf-Life of Food. J. Food Sci. Technol. 2016, 53, 3381-3394. [CrossRef]

5. Heymich, M.-L.; Friedlein, U.; Trollmann, M.; Schwaiger, K.; Böckmann, R.A.; Pischetsrieder, M. Generation of Antimicrobial Peptides Leg1 and Leg2 from Chickpea Storage Protein, Active against Food Spoilage Bacteria and Foodborne Pathogens. Food Chem. 2021, 347, 128917. [CrossRef]

6. van der Weerden, N.L.; Hancock, R.E.; Anderson, M.A. Permeabilization of Fungal Hyphae by the Plant Defensin Nad1 Occurs through a Cell Wall-Dependent Process. J. Biol. Chem. 2010, 285, 37513-37520. [CrossRef]

7. Thomas, D.S. Yeasts as Spoilage Organisms in Beverages. In The Yeasts, 2nd ed.; Rose, A.H., Harrison, J.S., Eds.; Academic Press: London, UK, 1993; pp. 517-561.

8. Pitt, J.I.; Hocking, A.D. Fungi and Food Spoilage, 2nd ed.; Springer: London, UK, 1997.

9. James, S.A.; Stratford, M. Spoilage Yeasts with Emphasis on the Genus Zygosaccharomyces. In Yeasts in Food; Boekhout, T., Robert, V., Eds.; Woodhead Publishing Series in Food Science, Technology and Nutrition; Woodhead Publishing: Cambridge, UK, 2003; pp. 171-191.

10. Stratford, M.; Steels, H.; Nebe-von-Caron, G.; Novodvorska, M.; Hayer, K.; Archer, D.B. Extreme Resistance to Weak-Acid Preservatives in the Spoilage Yeast Zygosaccharomyces Bailii. Int. J. Food Microbiol. 2013, 166, 126-134. [CrossRef] [PubMed]

11. Steels, H.; James, S.A.; Roberts, I.N.; Stratford, M. Sorbic Acid Resistance: The Inoculum Effect. Yeast 2000, 16, 1173-1183. [CrossRef]

12. Arendrup, M.C.; Meletiadis, J.; Mouton, J.W.; Lagrou, K.; Hamal, P.; Guinea, J. Subcommittee on Antifungal Susceptiblitiy Testing (AFST) of the ESCMID European Committee for Antimicrobial Susceptibility Testing. In Eucast Definitive Document E.Def 7.3.1 Method for the Determination of Broth Dilution Minimum Inhibitory Concentratins of Antifungal Agents for Yeasts; ESCMID European Committee for Antimicrobial Susceptiblity Testing-EUCAST: Växjö, Sweden, 2017.

13. Arendrup, M.C.; Guinea, J.; Cuenca-Estrella, M.; Meletiadis, J.; Mouton, J.W.; Lagrou, K.; Howard, S.J. Subcommittee on Antifungal Susceptiblitiy Testing (AFST) of the ESCMID European Committee for Antimicrobial Susceptibility Testing. In Eucast Definitive Document E. Def 9.3 Method for the Determination of Broth Dilution Minimum Inhibitory Concentrations of Antifungal Agents for Conidia Forming Moulds Version 9.3; The European Committee on Antimicrobial Susceptibility Testing-EUCAST: Växjö, Sweden, 2015.

14. Sarker, S.D.; Nahar, L.; Kumarasamy, Y. Microtitre Plate-Based Antibacterial Assay Incorporating Resazurin as an Indicator of Cell Growth, and Its Application in the in Vitro Antibacterial Screening of Phytochemicals. Methods 2007, 42, 321-324. [CrossRef]

15. Chen, J.; Yang, J.; Ma, L.; Li, J.; Shahzad, N.; Kim, C.K. Structure-Antioxidant Activity Relationship of Methoxy, Phenolic Hydroxyl and Carboxylic Acid Groups of Phenolic Acids. Sci. Rep. 2020, 10, 2611. [CrossRef] [PubMed]

16. Chu, Y.H.; Chang, C.L.; Hsu, H.F. Flavonoid Content of Several Vegetables and Their Antioxidant Activity. J. Sci. Food Agr. 2000, 80, 561-566. [CrossRef]

17. Brul, S.; Coote, P. Preservative Agents in Foods. Mode of Action and Microbial Resistance Mechanisms. Int. J. Food Microbiol. 1999, 50, 1-17. [CrossRef]

18. Mohammadi Azad, Z.; Moravej, H.; Fasihi-Ramandi, M.; Masjedian, F.; Nazari, R.; Mirnejad, R.; Moosazadeh Moghaddam, M. In Vitro Synergistic Effects of a Short Cationic Peptide and Clinically Used Antibiotics against Drug-Resistant Isolates of Brucella Melitensis. J. Med. Microbiol. 2017, 66, 919-926. [CrossRef] [PubMed]

19. Kampshoff, F.; Willcox, M.D.P.; Dutta, D. A Pilot Study of the Synergy between Two Antimicrobial Peptides and Two Common Antibiotics. Antibiotics 2019, 8, 60. [CrossRef]

20. Lopez-Exposito, I.; Pellegrini, A.; Amigo, L.; Recio, I. Synergistic Effect between Different Milk-Derived Peptides and Proteins. J. Dairy Sci. 2008, 91, 2184-2189. [CrossRef]

21. Stanojevic, D.; Comic, L.; Stefanovic, O.; Solujic-Sukdolak, S. Antimicrobial Effects of Sodium Benzoate, Sodium Nitrite and Potassium Sorbate and Their Synergistic Action in Vitro. Bulg. J. Agric. Sci. 2009, 15, 308-312.

22. Yeaman, M.R.; Yount, N.Y. Mechanisms of Antimicrobial Peptide Action and Resistance. Pharmacol. Rev. 2003, 55, 27-55. [CrossRef] [PubMed]

23. Georgopapadakou, N.H.; Walsh, T.J. Antifungal Agents: Chemotherapeutic Targets and Immunologic Strategies. Antimicrob. Agents Chemother. 1996, 40, 279-291. [CrossRef]

24. Letscher-Bru, V.; Herbrecht, R. Caspofungin: The First Representative of a New Antifungal Class. J. Antimicrob. Chemother. 2003, 51, 513-521. [CrossRef] [PubMed]

25. Free, S.J. Fungal Cell Wall Organization and Biosynthesis. Adv. Genet. 2013, 81, 33-82. [CrossRef]

26. Gastebois, A.; Clavaud, C.; Aimanianda, V.; Latge, J.P. Aspergillus Fumigatus: Cell Wall Polysaccharides, Their Biosynthesis and Organization. Future Microbiol. 2009, 4, 583-595. [CrossRef] [PubMed] 
27. Lesage, G.; Bussey, H. Cell Wall Assembly in Saccharomyces Cerevisiae. Microbiol. Mol. Biol. Rev. 2006, 70, 317-343. [CrossRef]

28. Grillitsch, K.; Tarazona, P.; Klug, L.; Wriessnegger, T.; Zellnig, G.; Leitner, E.; Feussner, I.; Daum, G. Isolation and Characterization of the Plasma Membrane from the Yeast Pichia Pastoris. Biochim. Biophys. Acta 2014, 1838, 1889-1897. [CrossRef] [PubMed]

29. James, S.A.; Collins, M.D.; Roberts, I.N. Genetic Interrelationship among Species of the Genus Zygosaccharomyces as Revealed by Small-Subunit Rrna Gene Sequences. Yeast 1994, 10, 871-881. [CrossRef] [PubMed]

30. Kurtzman, C.P. Discussion of Teleomorphic and Anamorphic Ascomycetous Yeasts and Yeast-Like Taxa. In The Yeasts. A Taxonomic Study, 5th ed.; Kurtzman, C.P., Fell, J.W., Boekhout, T., Eds.; Burlington: London, UK; Elsevier Science: San Diego, CA, USA, 2011; pp. 293-307.

31. Nguyen, T.H.; Fleet, G.H.; Rogers, P.L. Composition of the Cell Walls of Several Yeast Species. Appl. Microbiol. Biotechnol. 1998, 50, 206-212. [CrossRef] [PubMed]

32. Hazan, R.; Levine, A.; Abeliovich, H. Benzoic Acid, a Weak Organic Acid Food Preservative, Exerts Specific Effects on Intracellular Membrane Trafficking Pathways in Saccharomyces Cerevisiae. Appl. Environ. Microbiol. 2004, 70, 4449-4457. [CrossRef] [PubMed]

33. Thomas, L.V.; Delves-Broughton, J. Nisin. In Antimicrobials in Food; Davidson, P.M., Sofos, J.N., Branen, A.L., Eds.; CRC Press, Taylor \& Francis Publishing Group: Boca-Raton, FL, USA, 2005; pp. 237-274.

34. Dielbandhoesing, S.K.; Zhang, H.; Caro, L.H.; van der Vaart, J.M.; Klis, F.M.; Verrips, C.T.; Brul, S. Specific Cell Wall Proteins Confer Resistance to Nisin Upon Yeast Cells. Appl. Environ. Microbiol. 1998, 64, 4047-4052. [CrossRef]

35. Gossler-Schofberger, R.; Hesser, G.; Muik, M.; Wechselberger, C.; Jilek, A. An Orphan Dermaseptin from Frog Skin Reversibly Assembles to Amyloid-Like Aggregates in a Ph-Dependent Fashion. FEBS J. 2009, 276, 5849-5859. [CrossRef]

36. Raghuraman, H.; Chattopadhyay, A. Effect of Ionic Strength on Folding and Aggregation of the Hemolytic Peptide Melittin in Solution. Biopolymers 2006, 83, 111-121. [CrossRef]

37. Rao, B.D.; Chakraborty, H.; Keller, S.; Chattopadhyay, A. Aggregation Behavior of Phlip in Aqueous Solution at Low Concentrations: A Fluorescence Study. J. Fluoresc. 2018, 28, 967-973. [CrossRef] [PubMed]

38. Subbarao, N.K.; Parente, R.A.; Szoka, F.C., Jr.; Nadasdi, L.; Pongracz, K. Ph-Dependent Bilayer Destabilization by an Amphipathic Peptide. Biochemistry 1987, 26, 2964-2972. [CrossRef]

39. Zou, T.B.; He, T.P.; Li, H.B.; Tang, H.W.; Xia, E.Q. The Structure-Activity Relationship of the Antioxidant Peptides from Natural Proteins. Molecules 2016, 21, 72. [CrossRef] [PubMed]

40. Power, O.; Jakeman, P.; FitzGerald, R.J. Antioxidative Peptides: Enzymatic Production, in Vitro and in Vivo Antioxidant Activity and Potential Applications of Milk-Derived Antioxidative Peptides. Amino Acids 2013, 44, 797-820. [CrossRef] [PubMed]

41. Ayala-Nino, A.; Rodriguez-Serrano, G.M.; Gonzalez-Olivares, L.G.; Contreras-Lopez, E.; Regal-Lopez, P.; Cepeda-Saez, A. Sequence Identification of Bioactive Peptides from Amaranth Seed Proteins (Amaranthus Hypochondriacus Spp.). Molecules 2019, 24, 3033. [CrossRef] [PubMed]

42. Chen, H.M.; Muramoto, K.; Yamauchi, F.; Fujimoto, K.; Nokihara, K. Antioxidative Properties of Histidine-Containing Peptides Designed from Peptide Fragments Found in the Digests of a Soybean Protein. J. Agric. Food Chem. 1998, 46, 49-53. [CrossRef] [PubMed]

43. Ajibola, C.F.; Fashakin, J.B.; Fagbemi, T.N.; Aluko, R.E. Effect of Peptide Size on Antioxidant Properties of African Yam Bean Seed (Sphenostylis Stenocarpa) Protein Hydrolysate Fractions. Int. J. Mol. Sci. 2011, 12, 6685-6702. [CrossRef]

44. Sangtitanu, T.; Sangtanoo, P.; Srimongkol, P.; Saisavoey, T.; Reamtong, O.; Karnchanatat, A. Peptides Obtained from Edible Mushrooms: Hericium Erinaceus Offers the Ability to Scavenge Free Radicals and Induce Apoptosis in Lung Cancer Cells in Humans. Food Funct. 2020, 11, 4927-4939. [CrossRef]

45. Wu, D.; Sun, N.; Ding, J.; Zhu, B.; Lin, S. Evaluation and Structure-Activity Relationship Analysis of Antioxidant Shrimp Peptides. Food Funct. 2019, 10, 5605-5615. [CrossRef]

46. Bueno-Gavilá, E.; Abellán, A.; Girón-Rodríguez, F.; Cayuela, J.M.; Tejada, L. Bioactivity of Hydrolysates Obtained from Chicken Egg Ovalbumin Using Artichoke (Cynara Scolymus L.) Proteases. Foods 2021, 10, 246. [CrossRef]

47. Jakubczyk, A.; Karas, M.; Stanikowski, P.; Rutkowska, B.; Dziedzic, M.; Zielinska, E.; Szychowski, K.A.; Binduga, U.E.; Rybczynska-Tkaczyk, K.; Baraniak, B. Characterisation of Biologically Active Hydrolysates and Peptide Fractions of Vacuum Packaging String Bean (Phaseolus Vulgaris L.). Foods 2020, 9, 842. [CrossRef]

48. Sambuy, Y.; De Angelis, I.; Ranaldi, G.; Scarino, M.L.; Stammati, A.; Zucco, F. The Caco-2 Cell Line as a Model of the Intestinal Barrier: Influence of Cell and Culture-Related Factors on Caco-2 Cell Functional Characteristics. Cell Biol. Toxicol. 2005, $21,1-26$. [CrossRef]

49. International Organization for Standardization. Iso 10993-5:2009, Biological Evaluation of Medical Devices-Part 5: Tests for In Vitro Cytotoxicity; Vernier: Geneva, Switzerland, 2009.

50. Ahmadi, S.; Ghollasi, M.; Hosseini, H.M. The Apoptotic Impact of Nisin as a Potent Bacteriocin on the Colon Cancer Cells. Microb. Pathog. 2017, 111, 193-197. [CrossRef] [PubMed]

51. Lewies, A.; Wentzel, J.F.; Miller, H.C.; Du Plessis, L.H. The Antimicrobial Peptide Nisin Z Induces Selective Toxicity and Apoptotic Cell Death in Cultured Melanoma Cells. Biochimie 2018, 144, 28-40. [CrossRef] [PubMed] 
52. Zainodini, N.; Hassanshahi, G.; Hajizadeh, M.; Khanamani Falahati-Pour, S.; Mahmoodi, M.; Mirzaei, M.R. Nisin Induces Cytotoxicity and Apoptosis in Human Asterocytoma Cell Line (Sw1088). Asian Pac. J. Cancer Prev. 2018, 19, 2217-2222. [CrossRef] [PubMed]

53. Vaucher, R.A.; Teixeira, M.L.; Brandelli, A. Investigation of the Cytotoxicity of Antimicrobial Peptide P40 on Eukaryotic Cells. Curr. Microbiol. 2010, 60, 1-5. [CrossRef] [PubMed]

54. Zhao, L.; Cao, Z.; Bian, Y.; Hu, G.; Wang, J.; Zhou, Y. Molecular Dynamics Simulations of Human Antimicrobial Peptide Ll-37 in Model Popc and Popg Lipid Bilayers. Int. J. Mol. Sci. 2018, 19, 1186. [CrossRef] 